\title{
The Problem-Solution Approach to Study Indonesian Literatures in a Global Context
}

\author{
Karisma Erikson Tarigan 18 (D) $\square$ Margaret Stevani ${ }^{2} 8$ (D) \\ ${ }^{12}$ Fakultas Pendidikan Bahasa Inggris, Universitas Katolik Santo Thomas Sumatera Utara, Indonesia \\ Corresponding Author: Karisma Erikson Tarigan, E-mail: erick_tarigan2006@yahoo.com
}

\section{ARTICLE INFORMATION ABSTRACT}

Received: June 07, 2021

Accepted: July 10, 2021

Volume: 1

Issue: 1

DOI: $10.32996 /$ ijts.2021.1.1.4

\section{KEYWORDS}

Problem-solution approach, Literary learning,

Global context
This study was aimed to describe the problems of learning literature and offered the solutions that were expected to overcome the problems of learning Indonesian literature in schools in a global context. This study used a qualitative approach and contextual methods through a literature study. The results of this study indicated that only through continuous efforts the problems of literary learning could be realized as follows: Students were needed to be guided to know literature in a fun way and instill longing. Students read literary works directly, not summaries or reviews. Students were given the freedom to convey various interpretations in discussing literary works. Every opinion or achievement of student work was given an award. The portion of literary appreciation must be prioritized in literary learning. Knowledge of theory, definition and literary history was sufficient to serve as secondary information when discussing literary works. Reading and writing skills were closely related to learning to appreciate literature. Literary appreciation began with reading activities, while literary expression was related to writing literary works. Thus, literacy development through literary learning in the form of reading habits and writing skills in turn was able to form a strong generation and can compete in a global life that was full of challenges.

\section{Introduction}

The fact showed that no nation wanted to enter a century in which some people were blind to read and paralyzed to write. People who were short-sighted would be out of date and did not know the development of science and technology. Therefore, the tradition of writing quality literature was needed to be instilled in students through school in the form of literary learning that was relevant to the situation and demands of the times.

Literature learning was necessary for students. The mission of literature included: (a) literary works as a tool to move the reader's thoughts to reality and helped someone to make a decision when dealing with problems, (b) literary works made themselves as a place where human values get their proper place and were disseminated, especially in modern life and serves as a counterweight to science and technology, and (c) literary works as a successor to the traditions of a nation to its contemporaries, (Wibowo, 2013:38--39). The three literary missions were very important because the expression of the soul, nuances of life, beauty, and everything were created in literature. Learning literature directly or indirectly would help students develop insight into traditions in human life, increased sensitivity to various personal problems and human society, even literature would increase students' knowledge of various technological and scientific concepts (Noor, 2011: 82). This was in accordance with the opinion which stated that literary appreciation learning had an effective mission, namely enriching students' experiences and making them responsive to surrounding events (Oemarjati in Rohmadi and Subiyantoro, 2011: 69). Therefore, Indonesian literature teachers should not ignore literary learning. Teachers were required to be creative and innovative so that literary learning was not boring and the ultimate goal was achieved.

The feeling of dissatisfaction with learning Indonesian literature had been expressed by the writer Pramoedya Ananta Toer in a literary symposium initiated by the Faculty of Letters, University of Indonesia, Jakarta around 1955 ago. The criticism that

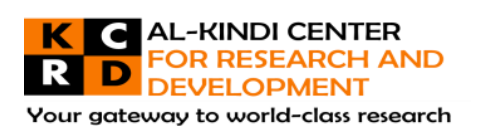

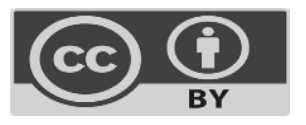

Published by Al-Kindi Center for Research and Development. Copyright (c) the author(s). This open access article is distributed under a Creative Commons Attribution (CC-BY) 4.0 license 
emphasizes the "negligence" corner of the teacher did not teach literature optimally because of the demands of the curriculum, relatively little learning time, inadequate facilities, and infrastructure in schools. The throw immediately received a warm welcome from A.T. Effendy as a "representative" teacher who felt he must carry out his duties and obligations as well as possible (Rosidi, 1991). The problem was that after 62 years, had the condition of learning literature in our schools to the date shown a significant change after discussion after discussion was held? Did it just stop as a discourse? An important question for us was, was the Indonesian literature in our schools had so far been considered a failure?

Research conducted by writers criticized literary learning that did not give a large portion of the habit of reading and writing to students. Students became "short of reading" because they did not get the task of reading literary books, honing, and fostering a culture of reading books in general. They went through the school library and became "crippled in writing" because there was no writing practice in school lessons. Writing exercises prepared people to be able to write in their respective fields, (Ismail, 2003). He suggested that literature lessons be separated from language lessons, and then stood alone. So far, literature lessons had only been inserted and taught only one-sixth part, so it was extraordinary at least. Meanwhile, the language teachers who were tasked with teaching literature were not fully trained and fully prepared to teach literature. In addition, the teaching of literary appreciation must present the literary work itself, therefore it needed the support of facilities. Teaching literature without literary works was nonsense. The literary work should be a published work. However, considering that the literary works that had been published were very limited, then presenting them in the form of photocopies was still acceptable.

Teaching Indonesian literature in schools had not fully supported the improvement of students' abilities and creativity. Students at certain levels were more likely to be directed to the introduction of certain linguistic concepts and formulas. To provoke students' creativity, it was necessary to seek some kind of stimulus to make them think. Literature teaching which was part of language teaching was still less useful in overcoming the "scarcity" of students' creativity. For that, it was the time for the frequency of teaching literature to get an adequate portion in teaching Indonesian.

In an effort to repair the failure of teaching literature, teachers could use Moody's literary appreciation learning theory as an alternative. This paper would describe the problems of learning literature, efforts to read literature as self-enrichment, and design learning literature that was fun and instills longing. This study was aimed to describe the problems of learning literature and would also offer solutions that were expected to overcome the problems of learning Indonesian literature in schools in a global context.

\section{Methodology}

The approach used in this study was a qualitative descriptive method based on a literature review. This approach was expected to provide a careful description of certain conditions or symptoms in the object of study. The data collection technique used was library research and documentation research. The source of the library that was used as a reference and the object of research was a book of literary works. The data analysis process was data reduction and presentation. Data reduction analysis was done by selecting, focusing, and simplifying what had been obtained based on library sources. This analysis was carried out to emphasize, summarize, focus and discard data that was not important so that conclusions could be drawn.

\subsection{Moody's Literary Appreciation Learning Theory as a Methodology}

The theory used in this research was literary appreciation learning theory by (Moody, 1971). According to the presentation procedure, literary appreciation learning follows the following stages. (1) preliminary tracking; (2) determination of practical attitude; (3) introduction/introduction; (4) presentation; (5) discussion; and (6) confirmation. The details of the six stages are presented as follows.

1. Preliminary tracking. At this stage, the teacher studied literary works to determine appropriate strategies and ways of presenting, aspects that needed special attention from students.

2. Determination of practical attitude. The practical attitude was how the teacher determined matters relating to the implementation of the presentation of literary appreciation learning. At this stage, the teacher must determine which literary works would be presented. The literary work to be presented should not be too long. Try literary works that could be presented in one meeting. Another thing that must be determined at this stage was what information needs to be given to students in order to make it easier for students to understand literary works. At this stage, the teacher must also determine when literary works were distributed. 
3. Introduction or introduction. At this stage, the teacher provided initial information in the form of a brief description of the work presented, including information about the author and the work of other authors. The teacher should explain the situation and conditions when a literary work was created.

4. Presentation stage. At this stage, the teacher must first believe in the nature of oral literature, especially poetry. At this stage, especially in poetry, it was better to read it aloud first. It would be better if, for example, there was a model for reading poetry from recorded poets. This model required only some kind of pattern, not one that must be followed exactly by imitating it. For short stories, one short story could be read in turn in front of the class after the students had read it silently. For novels, read one or two fragments of a novel that would interest students.

5. Discussion stage. At this stage, the teacher provided the widest opportunity for students to provide interpretations. Teachers were also trained to gradually provide the conditions for the situation of meaning in literary works so that students were able to express the meaning of the literary work being studied. In this section, students are given the opportunity to provide feedback without the intervention of the teacher. Teachers were still expected to have a "passive-wise" attitude. That was, if it was not necessary, the teacher must be able to refrain from "talking". If their discussion extends to things that were far from the discussion of literary works, redirect them, for example by citing the relevant part of the literary work being studied.

6. Strengthening understanding. Strengthening this understanding was aimed to strengthen students' understanding of the literary works studied. This confirmation could be done orally or in writing.

\section{Results and Discussion}

\subsection{Indonesian Literature Learning Problems}

Towards the face of the past global era, there was still a sluggishness in learning literature from elementary school to university. In relation to literature learning at this school, the thing that had also exacerbated the decline in literature teaching in the past 60 years was the result of the fertile life of the paradigm of "excessive superiority to the exact sciences department" (Ismail, 2003:9). Taufiq Ismail, at the VII Indonesian Language Congress, 26-30 October 1998, was still shouting loudly about "a nation that is blind in literature and paralyzed by writing". The main cause was the low quality of learning literature in schools. Thus, the main problem in learning literature in Indonesian schools is that students could not read literary works properly. In fact, the key to unlocking knowledge was reading, reading, and reading (Santoso, $2015: 2$ ).

In order for literature learning to be relevant to the situation and demands of the times, it was necessary to address two factors that were highlighted to support literature learning in schools in facing the upcoming global challenges, namely: (1) the role of teachers in understanding the concept of literary learning, (2) literary learning strategies that pleasing and instilling longing. The love of students for literary works would be able to arouse the enthusiasm of appreciation of literary works and enhanced knowledge in facing the competition of a century full of challenges (Wena, 2011:5). Literary learning was a world that relied on intuitive, imaginative, and creative abilities. Therefore, approaching literary works involved a lot of intuitive sensitivity, although intellectual or cognitive strength was still required. Thus, literary learning must be oriented towards developing students' intuitive and emotional abilities in an effort to understand the messages contained in a literary work. The process towards a comprehensive understanding of literature required intellectual ability, at least as a means of supporting it. The next target was the efforts to grow and develop a fair appreciation for all kinds of literary works from students. Thus, the main purpose of learning literature in schools was to grow and to develop students' appreciation of literary works.

Regarding the understanding of literary appreciation, it was better to pay attention to the understanding that was put forward (Oemarjati, 1991) in a paper entitled "Guiding Literature Appreciation in the Teaching and Learning Process". According to him, appreciation meant a sensitive response or understanding of the work. The keyword was "sensitive". On the one hand, the word referred to the affective aspect of a person's ability, not cognitive, on the other hand, the sensitivity concerned a person's affective response to the values, in this case, contained in a literary work. Therefore, appreciating literature meant responding to literature with affective abilities which on the one hand were sensitive to the values contained in the literary work concerned, both implied and expressed, within the underlying thematic framework. On the other hand, the sensitivity of the respondents wanted to understand the pattern of values obtained from reading in proportions that were in accordance with the context of the problem. As a result, literary learning should be directed.

It turned out that not all teachers who taught literature could understand the prioritized learning objectives. As a result, literary learning was always filled with theoretical materials, only requiring memorizing the history of literature as well as literary figures and their works. Students were introduced to the biography of Amir Hamzah but were not invited to explore the meaning and moral messages contained in his poems. Students might memorize the synopsis of Sutan Takdir Alisyahbana's Terkembang Screen or Dari Ave Maria to Another Way to Rome by Idrus, but did not want to see the relevance of its content to the living conditions 
they faced today. Conditions were certainly not "healthy" for the development of students' emotional and intellectual abilities. Literary learning was ultimately similar to learning history, geography, or biology which demanded more cognitive abilities than students' effective abilities.

The problem of misconceptions in literary learning above was related to, as Nadeak (1984) suspected, the lack of initiative from educators in an effort to foster students to "read" literary works as a whole. The teachers seemed to be satisfied to see that their students were able to read excerpts or a synopsis of a novel as many of them were presented in textbooks. As a result, the students only read very minimal reading material and in the end, their knowledge and understanding of literature became very shallow. The more important demand was the willingness of teachers to open themselves up in order to develop their professional abilities so that conceptual errors in literary learning did not need to occur repeatedly.

\subsection{Self-Enrichment as a Process of Reading Literatures}

Enrichment of students' insight into literature could be done through increased reading of literary works. However, the student's reading activity was not only able to spell letter by letter in a sentence. More emphasis was placed on achieving an understanding of the results of the reading process. Of course, the process of reading could enrich students' self was reading activities followed by understanding.

In relation to the activity of reading literature, reading was a process towards self-enrichment (Leksono, 1999: 4). By writing, someone would try to experiment with the dangers of words and their difficulty. Reading was access to knowledge and writing was a medium for spreading ideas (Leksono, 1999:4). For this reason, the improvement of reading and writing skills should be widely accepted by students in teaching Indonesian literature. Meanwhile, literary works could be used to achieve this goal. However, the literary works presented to students were works that were close to students. For this reason, a kind of wisdom was needed in determining the works presented in the teaching and learning process (Wolf, 1963).

Wisdom in choosing the works to be presented in the teaching and learning process was based on the fact that students' thinking was not uniform. Meanwhile, reading and understanding a literary work was a step of appreciation activity. The reason for someone's motivation to read literary works was personal. The understanding of students from one another was certainly different, depending on the problems at hand. Sometimes a person could see something in a literary work that was not necessarily seen by others. Therefore, students were given the freedom to appreciate the works that were used as teaching materials. Furthermore, it was the teacher's job to correct errors such as spelling, sentences, and terms (Sitanggang, 1992:52).

\subsection{Designing Fun Literary Learning for Indonesian Students}

The concept of fun learning always stuck out in the world of education. This concept was oriented towards educative interactions between teachers and students. As an educative interaction orientation, the practice of this concept was considered capable of realizing maximum learning processes and outcomes. All subject teachers were advised to design learning with fun methods and instill a longing, surely students would always look forward to literature lessons (Sayuti, 2017). As a result, students always missed the presence of literature lessons the following things that needed to be considered : (1) Provided opportunities for students to be open to new experiences through literature, not about literature; (2) Encouraged students to have the flexibility of thinking by involving them in the awareness that literature was a world of reflective consciousness; (3) Provided students with great opportunities for freedom in expressing their views according to their choice of language as a "private area"; (4) Encouraged and developed students' imagination power because the search for new alternatives almost always started with empowering imagination, and "good imagination must be reality-based".

The new perspective of teaching literature in schools should make students enter literature in a fun and happy way. Students directly read literary works, such as poetry, short stories, novels, plays, and essays. Not through the summary. Writing classes must be held in a fun way, and when discussing literary works, various interpretations must be respected, and knowledge of literature, both theory, definition, and history was important. Most importantly, teaching literature must educate students' character, build student behavior, and sow noble values and noble character traits in students (Ismail, 2003).

An example of a literary learning design that was fun and instills longing was as follows. First, preliminary tracking was important to find the right way of presenting literary appreciation learning by considering the following: who was the target of the poet/poet, whether a certain person or human in general, how the author presents his work. Was the author in this case the poet using a 
monologue style in the poem? What did the "I Want" in the rhyme serve as? whether the literary work had an implied or explicit meaning.

1. Chose the poem. The teacher studied the poem entitled "I Want" by Sapardi Djoko Damono. The teacher determined the right strategy, could determine aspects that need special attention from students. For example, strong repetition of certain lines of poetry. Why was this repetition so strong? What was the meaning? Did it not had any effect on this poem as a whole? If there was an effect, what was the effect of this repetition?

2. Determination of critical attitude. The teacher distributed the text of the poem "I Want" by Sapardi Djoko Damono. The students were asked to write the poem in his book.

3. Introduction. The teacher asked the students if they had ever known the name of the poet Sapardi Djoko Damono? The teacher responded to the students' answers by explaining a bit of Sapardi Djoko Damono's bio. Some students already knew the name of the poet but there were some students who did not know Sapardi Djoko Damono.

4. Presentation. Some students were asked to come to the front of the class to read the text of the poem "I Want" by Sapardi Djoko Damono aloud. Meanwhile, students who did not come to the front of the class were asked to listen to the text of the poetry reading. This poem could be read by a student or teacher or a model reader or writer (in the form of a recording). Techniques were needed to read poetry, there were four things, namely : (1) reading completely without stopping, it did not matter if students could understand or not; (2) read the poem in its entirety, and read it aloud; (3) understood poetry in its unity, even though the understanding is vague; (4) reading poetry repeatedly (Adler \& Doren, 2012: 257-259). Below was an example of poetry :

\author{
I WANT \\ by Sapardi Djoko Damono \\ I want to love you with simple, \\ with unspoken words \\ wood to a fire that turns it to ashes. \\ I want to love you with simple, \\ with a sign that could not be conveyed \\ cloud to the rain that makes it nothing.
}

5. Discussion. Students were allowed to ask questions about difficult words that had not yet been understood. Students were assigned to write and answer questions. The teacher could make questions by dictating or writing them on the board. Asked questions that were provoking and directed their discussion such as the following questions :

a. What was the general impression of the poem?

b. In particular, what was the impression of the poem?

c. What was the general idea of the poem talking about?

d. How was that idea embodied in poetry?

e. What were the linguistic means to make this happen?

$\mathrm{f}$. What was the meaning of this poem as a whole?

These questions could be identified as a number of more questions. In addition, the students and the teacher discussed the themes, meanings, and messages contained in the text of the poem "I Want" by Sapardi Djoko Damono. Students were given the opportunity to answer these questions along with their arguments. Students and teachers discussed things that students did not understand. Let students drew their own conclusions. If they reached a dead end or if their discussion widened to things that were far from the discussion of literary works, redirected them, for example by citing the relevant part of the literary work being studied. The lesson was closed with a lesson that encouraged the students' motivation to study hard.

6. Confirmation. Each student read a poem in front of the class, not individually. This poem could be read for the second time or even for the third or fourth time together by two or three students. The reading formation could be varied by the teacher 
according to the conditions faced. The most important thing from this activity was that students got other effects that make them enjoyed poetry more when compared to reading them individually. Another way the teacher could ask students to change the genre of literary works, for example from poetry to short stories or vice versa.

\section{Conclusion}

Based on the research on literary studies, several things needed to be concluded related to literacy development through literary learning in the form of reading habits and writing skills which in turn were able to form a tough generation and could compete in a global life that was full of challenges. Students needed to be guided to get to know literature in a fun way and instill longing. Students read literary works directly, not summaries or reviews. Students were given the freedom to convey various interpretations in discussing literary works. Every opinion or achievement of student work was given an award. The portion of literary appreciation must be prioritized in literary learning. Knowledge of theory, definition and literary history was sufficient to serve as secondary information when discussing literary works. Reading and writing skills were closely related to learning to appreciate literature. Literary appreciation began with reading activities, while literary expression was related to writing literary works.

Funding: This research received no external funding.

Conflicts of Interest: The authors declare no conflict of interest.

\section{References}

[1] Adler, M., \& Charles V. N. (2012). How to Read a Book. Jakarta: Indonesian Publishing.

[2] Ismail, T. 2003. So that the Nation's Children are not Bblind to Read and not Crippled to Compose". Inaugural Speech. Yogyakarta: Yogyakarta University.

[3] Leksono, K. (1999). Reading and Writing: An Enrichment of Existence. Paper presented at the Symposium on the Role of Books in Indonesia's New Society organized by the Indonesian Obor Foundation in February 1999.

[4] Moody, H. L. B. (1971). The Teaching of Literature. London: Longman Group Limited.

[5] Nadeak, W. (1984). Overview of the World of Indonesian Literature. Flores: Nusa Indah.

[6] Noor, R. M. 2011. Literature-Based Character Education: An Effective Moral Education Solution. Yogyakarta: Ar-Ruzz Media.

[7] Oemarjati, B. (1991). "Guiding Literature Appreciation in the Teaching and Learning Process" in Bambang Kaswanti Purwo (Ed). Literature and Language: Renewal of Teaching. Yogyakarta: Kanisius.

[8] Rohmadi, M., \& Slamet-Subiyantoro. 2011. Anthology: Models of Language, Literature, and Art Learning. Surakarta: Yuma Pustaka.

[9] Rosidi, J. (1991). Overview of the History of Indonesian Literature. Jakarta: Bina Cipta.

[10] Santosa, P., \& Djamari. 2015. Literature Learning Strategy A: In the Era of Globalization. Yogyakarta: Azzagrafika.

[11] Sayuti, S. (2017_. Avoiding Deadlock in Teaching Indonesian Language and Literature. Paper presented at the National Discussion in Linguistic and Literary Perspective organized by the Language Development and Development Agency, Ministry of Education and Culture on March 1, 2017.

[12] Sitanggang, S. R. H. (1992). Women and Tradition: A Study of Egypt, Algeria, and Uganda in Language and Literature. Jakarta : Indonesian Publishing.

[13] Wena, M. (2011). Contemporary Innovative Learning Strategies An Operational Conceptual Review. Jakarta: Earth Literacy.

[14] Wibowo, A. (2013). Literature-Based Character Education. Yogyakarta: Student Library.

[15] Woolf, V. (1963). How Should One Read a Book in Gateway to the Great Books: Critical Essay. London: William Benton. 